\title{
A construção social do gênero
}

\author{
Psicologia do gênero: \\ psicobiografia, sociocultura e \\ transformações.
}

\author{
FÁVERO, Maria Helena.
}

Curitiba: UFPR, 2010.

Maria Helena Fávero, professora do Instituto de Psicologia da Universidade de Brasília, no livro Psicologia do gênero: psicobiografia, sociocultura e transformações, aponta a necessidade de se ultrapassarem os limites do senso comum para explicar a diferença entre os gêneros. A autora repudia a concepção simplista que naturaliza (para justificar) as práticas gendradas (como nas relações hierarquizadas, nas relações interpessoais e na sexualidade). É a chamada "naturalização" ou "biologização" de questões que são socializadas e construídas. Fávero aponta que a tomada de consciência do mundo dos significados, que fundamenta determinadas práticas sociais relativas ao gênero, é essencial para a promoção de mudanças. Ela rejeita categoricamente a ideia determinista da impossibilidade de transformação de atitudes pessoais e interpessoais nesse plano. Se convidado a refletir e a questionar armadilhas conceituais e epistemológicas, o homem/mulher é capaz de se desprender de padrões de comportamento "naturalizados", ou seja, é capaz de escapar de círculos viciosos de determinadas práticas sociais consolidadas. A autora defende que o ponto central da construção da subjetividade e da identidade dos gêneros reside na emoção, na maneira como essa é entendida e atribuída a significados ditos "femininos" ou "masculinos", ou seja, "o núcleo central da socialização do gênero é a socialização das diferenças nas expressões emocionais" (p. 127) (como apego, medo, raiva, culpa), que mantêm a dicotomia dos papéis de gênero e das relações de poder. Além disso, Fávero faz uma extensa revisão da literatura nacional e internacional, com um panorama crítico sobre os temas atuais mais marcantes na área de pesquisa da psicologia do gênero.

O livro é dividido em três partes: a primeira (Capítulos 1 e 2) fundamenta a construção histórica da dicotomia feminino versus masculino; a segunda (Capítulos 3 e 4) identifica práticas pessoais e sociais consolidadas relativas ao gênero; e a terceira (Capítulos 5 e 6) aponta a assimetria do gênero estampada no discurso de homens e mulheres.

No Capítulo 1, a autora faz uso do conceito de mediação semiótica para defender sua tese de que as relações de gênero são construídas. Em nossa sociocultura, a experiência do feminino e do masculino faz referência a significados particulares, representados nas brincadeiras e nos brinquedos infantis, na moda, nas telenovelas, dentre muitos exemplos. Não pouco frequente, o discurso da ciência, incluindo o da Psicologia, também é usado (ou mal-usado) para legitimar e dar credibilidade a disparates do que é "natural" do homem (ex.: competição, força, intelecto) versus o "natural" da mulher (ex.: fragilidade, delicadeza). Fávero ressalta, então, a importâcia do conceito de mediação semiótica no desenvolvimento e no entendimento desses significados estabelecidos e "naturalizados". Ela questiona a dualidade feminino versus masculino, e defende a premissa de que esse dualismo é artificial e construído, e, portanto, pode ser desconstruído e reconstruído em uma nova forma, tanto do ponto de vista pessoal quanto institucional.

Partindo da dualidade acima descrita, o Capítulo 2 procura responder como a catego- 
rização do que é feminino e do que é masculino foi criada, perdurou ao longo do tempo e que consequências trouxe. Fávero descreve como, a partir do paradigma do patriarcado, se deu a "naturalização" daquilo que era tido como "típico" feminino ou masculino e ressalta o importante papel do movimento feminista no questionamento desse paradigma e na transformação de práticas sociais. A autora aponta algumas concepções (ou "equívocos") que permeiam o paradigma patriarcal, como, por exemplo, a noção de "privilégio biológico" do homem, o parto e a maternidade como o "destino biológico" da mulher e o mito do amor materno. O ponto crucial do processo de "biologização" de características ditas "femininas" ou "masculinas" é a dicotomia emoção versus razão, que dá suporte à tese de que homens são guiados pelo racional e mulheres pela emoção. Como em nossa cultura há maior valorização da razão em detrimento da emoção, essa suposta dicotomia se configura até hoje como uma das justificativas da relação de poder do homem sobre a mulher. Essa é apenas uma das facetas do patriarcado contemporâneo que aparecem no século XXI, sob nova forma e dissimulado discurso, nas mídias, nas instituições educacionais, na falocracia e na desigualdade de gêneros.

O Capítulo 3 foca-se fundamentalmente nas emoções, trazendo evidências de que meninos e meninas são mais parecidos do que diferentes no que diz respeito ao tema. Os estudos apontam que a maneira como se expressam os sentimentos depende de múltiplas variáveis como idade, etnia, classe social, circunstância, gênero e crenças quanto à expressão de emoções. A grande questão parece ser a de que as mulheres, devido à forma com que são socializadas, expressam as emoções com maior frequência que os homens, mas não necessariamente as experienciam mais. Mediante processos sociais evidentes (diante das expectativas de papéis sociais diferentes para cada um dos gêneros), o que se observa é que a expressão de emoções distintas é aceitável para um gênero, mas não para o outro (ex.: tristeza, medo e vergonha para mulheres e raiva e competitividade para homens). Dito de outra forma, meninos e meninas desenvolvem maneiras diferentes de expressão de suas emoções conforme o padrão de apoio social que recebem, mas não por razões biológicas. Esse modelo de socialização baseado no ideal feminino (de fragilidade e vulnerabilidade) e no ideal masculino (de potência e força) traz prejuízos sociais em práticas de gênero nem sempre evidentes ou intencionais, como no cuidado com a saúde, nas escolhas profissionais, no contexto de trabalho e nas atividades domésticas.

No Capítulo 4, o mais longo e, provavelmente, a espinha dorsal do livro, a autora, a partir de minuciosa revisão bibliográfica nacional e internacional, analisa as principais questões na área de psicologia do gênero: iniciação sexual, corpo, emoção, autoestima, envelhecimento e violência. Em termos gerais, a revisão da literatura aponta que a) a pesquisa da sexualidade tem sido historicamente marcada pela masculinidade e a heterossexualidade como linha de base normativa; b) as pesquisas de iniciação sexual no Brasil ainda mostram dados fortemente atrelados a papéis tradicionais de gênero no relato de moças e rapazes; c) questões socioculturais relativas ao gênero conduzem a mulher ao "projeto disciplinador da feminilidade", a chamada "objetificação sexual" da mulher, em que seu valor fica reduzido à sua aparência ? explicando a busca exagerada pelo corpo ideal, o aumento das taxas de transtornos alimentares e os recordes de cirurgia plástica no Brasil; d) a violência é gendrada (a prevalência dos diferentes tipos de abuso infantil varia conforme o gênero da criança e há notável assimetria entre as taxas de crimes cometidos por homens e por mulheres); e) quanto maior a desigualdade de gênero, mais altas são as taxas de violência contra a mulher; f) a violência sexual contra a mulher está intimamente atrelada ao conceito de hipermasculinidade (força, dominação e desejo) e hipersexualização (em que socialmente a atividade sexual é encorajada como parte intrínseca e, portanto, inevitável da masculinidade); g) no entanto, pesquisas nos últimos anos mostram que a violência por mulheres contra homens tem maior prevalência do que o esperado, traindo o papel de vitimização que a mulher frequentemente assume; e h) sexualidade, autoimagem, relacionamentos, discriminação e vitimização referente ao grupo de homossexuais, bissexuais e transexuais ainda são negligenciados em pesquisas sobre gênero.

Na terceira e última parte do livro, Fávero foca-se no discurso da cultura, identificando aspectos gendrados subliminares nas narrativas que permeiam relações na família (Capítulo 5), na sexualidade e na intimidade (Capítulo 6).

A área de psicologia do gênero ainda é incipiente nos currículos de Psicologia e Sociologia no Brasil. O livro de Maria Helena Fávero, a partir de um notável diálogo entre a literatura nacional e a internacional, faz uma 
profunda reflexão sobre a origem do processo de construção dos gêneros, sobre as práticas e as narrativas com conteúdo gendrado (nem sempre evidente) e suas implicações no mundo atual. A possibilidade de mudança é pautada na tomada de consciência e pensamento crítico quanto aos papéis de gênero ainda profundamente enraizados na nossa cultura: "se há construção é possível reconstruir" (p. 24). Como muitos debates sociais relativos às mídias, à educação, à socialização e à violência têm como pano de fundo questões relativas ao gênero, o livro traz uma importante contribuição à área de psicologia do gênero no Brasil e implementa discussões nas mais diferentes disciplinas.

Lylla Cysne Frota D'Abreu Universidade de Potsdam, Alemanha 